\title{
ANALISIS PEMBIAYAAN MUDHARABAH PADA BANK SYARIAH INDONESIA KC MAKASSAR PETTARANI
}

\author{
HIKMAH \\ hiikmah.raahman12@gmail.com \\ INSTITUT BISNIS DAN KEUANGAN NITRO
}

\begin{abstract}
ABSTRAK
Judul penelitian ini adalah "Analisis Pembiayaan Mudharabah Pada Bank Syariah Indonesia Kc Makassar Pettarani” penelitian ini bertujuan untuk mengetahui tingkat pembiayaan mudharabah yang terjadi pada Bank Syariah Indonesia Kc Makassar Pettarani. Metode analisiis yang digunakan dari penelitian ini adalah metode deskriptif kuantitatif yaitu seberapa besar tingkat pembiayaan mudharabah di Bank Syariah Indonesia KC Makassar Pettarani. Teknik penelitian yang digunakan adalah penelitian lapangan dan penelitian pustaka. Adapun metode penelitian yang digunakan adalah metode kualitatif.
\end{abstract}

Kata Kunci: Pembiayaan, Pembiayaan Mudharabah, Bagi Hasil

\section{PENDAHULUAN}

Menurut UU RI no. 10 tahun 1998 tanggal 101998 dalam Marimin \& Dkk (2015) tentang perbankan, yang dimaksud dengan bank adalah "badan usaha yang menghimpun dana dari mesarakat dalam bentuk kredit atau bentukbentuk lainnya dalam rangka meningkatkan taraf hidup rakyat banyak". Dari pengertian diatas, dapat dipahami bahwa bank merupakan perusahaan yang bergerak dibidang keuangan dan segala aktivitasnya selalu berkaitan dengan keuangan. Adapun dalam menjalankan kegiatan usahanya, bank di indonesia dibedakan menjadi dua yaitu bank yang melaksanakan kegiatan usaha berdarkan prinsip konvensional, dan berdasarkan prinsip syariah.

Menurut Machmud dalam Daga (2021) saat ini perbankan syariah semakin berkembang, hampir semua perbankan memiliki sistem syariah yang menawarkan 
produk keuangan dan investasi dengan cara yang berbeda dibanding bank konvensional yang sudah lama ada. Meskipun masih dianggap newbile, perbankan syariah di negara qatar, turki, dan malaysia berkembang cukup pesat, termasuk di inggris yang mayoritas warganya non muslim, mereka menganngap bahwa bank syariah itu transparan, jujur dan mengutamakan kesejahteraan masyarakat. Negara indonesia merupakan negara muslim terbesar dunia yang masih kurang berkembang dalam perbankan syariah yang disebabkan minimnya pengetahuan masyarakat indonesia mengenai perbankan syariah. Kurangnya dukungan masyarakat indonesia, serta pengaruh budaya yang masih nyaman menggunakan produk konvensional, sehingga perbankan syariah sulit untuk berkembang pesat, namun perbankan masih menghadirkan sistem syariah di Indonesia.

Salah satu bukti perkembangan dari bank syariah itu sendiri adalah dengan didirikannya bank syariah indonesia, dimana bank ini merupakan gabungan dari bank bumn yaitu bank bri syariah, bank mandiri syariah dan bank bni syariah. Dimana bank ini diharapakan menjadi salah satu bank syariah terbesar di indonesia selain bank muamalat.

Bank syariah sendiri memiliki fungsi yang sama dengan bank umum yaitu menghimpun dana dan menyalurkan dana dalam bentuk pembiayaan kepada masayarakat. Pembiayaan dibank syariah itu sendiri memiliki akad yang berbedabeda tergantung kebutuhan dari nasabah yang mengajukan pembiayaan. Salah satu akad dari pembiayaan dibank syariah adalah akad mudharabah.

Menurut Ardiansyah (2012) mudharabah adalah suatu perumpamaan (ibarat) seseorang yang memberikan (menyerahkan) harta benda (modal) kepada orang lain agar digunakan perdagangan yang menghasilkan keuntungan bersama dengan syarat-syarat tertentu dan jika rugi maka kerugian di tanggung pemilik modal

Akad mudharabah salah satu produk pembiayaan dalam prinsip bagi hasil. Akan tetapi pembiayaan mudharabah termasuk salah satu akad yang jarang digunakan atau kurang diminati oleh masyarakat. Kebanyakan dari masyarakat lebih sering melakukan akad jual beli karena dianggap lebih baik dibanding dengan akad bagi hasil. Adapun alasan kenapa akad bagi bagi hasil khususnya akad mudharabah kurang diminati karena lembaga keuangan seperti bank syariah tidak dapat 
memastikan apakah pengusaha dalam hal mengelolah usahanya akan untung atau rugi. Dengan adanya resiko ini bank dituntut harus ekstra hati-hati dalam hal pemberian pembiayaan mudharabah kepada calon nasabah.

Oleh karenaa itu, bank menjadi sangat berhati-hati dalam pemberian pembiayan mudharabah. Pembiayaan dengan prinsip bagi hasil apabila kedua belah pihak yang bersangkutan tidak dapat memahami maka resiko yang ditimbulkan akan sangat besar. Berdasarkan latar belakaang dipaparkan diatas, maka peneliti tertarik untuk melakukan penelitian dengan judul "Analisis Pembiayaan Mudharabah Pada Bank Syariah Indonesia KC Makassar Pettarani".

\section{TINJAUAN PUSTAKA}

\section{Pembiayaan}

\section{1) Pengertian Pembiayaan}

Menurut Kusumawati, Dkk, dalam Daga (2021) pembiayaan adalah pendanaan yang dikeluarkan oleh lembaga pembiaayaan seperti bank syariah kepada nasabah. Pembiayaaan mempunyai peranan yang sangat penting dalam perekonomian. Seacara garis besar fungsi pembiayaan didalam perekonomian, perdagangan, dan keuangan dapat dikemukakan sebagai berikut: pembiayaan dapat meningkatkan utility (daya guna) dari modal/uang pembiayaan meningkatkan utility (daya guna) suatu barang pembiayaan meningkatkan peredaran dan lalu lintas barang pembiayaan menimbulkan gairah usaha masyarakatpembiayaan sebagai alat stabilitasi ekonomi. Secara umum, skema besar pembiayaan dapat dapat dibagi menjadi dua bagian besar, antara lain: pembiayaan produktif, dan pembiayaan konsumtif. Adapun perbedaan perlakuan antara pembiayaan konsumtif dan produktif terletak pada metode pendekatan analisisnya. Pada pembiayaan konsumtif, fokus analisis dilakukan pada kemampuan finansial pribadi dalam mengembalikan pembiayaan yang telah diterimanya seperti gaji. Sedangkan pada produktif, fokus analisis diarahkan pada kemampuan finansial usaha untuk melunasi pembiayaan yang telah diterimanya. 


\section{2) Tujuan Pembiayaan}

Menurut Rimadhani \& Erza(2017) tujuan pembiayaan berdasarkanprinsip syariah adalah untuk meningkatkan kesempatan kerja dan kesejahteraan ekonomi sesuai dengan nilai-nilai islam. Pembiayaan tersebut harus dapat dinikmati oleh sebanyak-banyaknya pengusaha yang bergerak dibidang industri, pertanian, dan perdagangan untuk menunjang kesempatan kerja dan menunjang produksi dan distribusi barang-barang dan jasa-jasa dalam rangka memenuhi kebutuhan dalam negeri maupun ekspor.

Menurut Muhammad dalam Rimadhani \& Erza(2017), membedakan tujuan pembiayaan menjadi dua kelompok, yaitu: tujuan pembiayaan untuk tingkat makro, dan tujuan pembiayaan untuk tingkat mikro. Secara makro, pembiayaan bertujuan untuk :

a. Peningkatan ekonomi umat. Masyarakat yang tidak dapat akses secara ekonomi, dengan adanya pembiayaan mereka dapat melakukan akses ekonomi.ndengan demikian dapat meningkatkan taraf ekonominya

b. Tersedianya dana bagi peningkatan usaha. Untuk pengembangan usaha membutuhkan dana. Dana tambahan ini dapat diperoleh dengan melakukan aktivitas pembiayaan. Pihak yang surplus dana menyalurkan kepada pihak minus dana, sehingga dapat tergulirkan.

c. Meningkatkan produktivitas. Pembiayaan memberikan peluang usaha bagi masyarakat agar mampu meningkatkan daya produksinya. Sebab upaya produksi tidak akan dapat jalan tanpa adanya dana

d. Membuka lapangan kerja baru. Dengan dibukanya sektor-sektor usaha melalui penambahan dana pembiayaan, maka sektor usaha tersebut akan menyerap tenaga kerja. Hal ini berarti menambah atau membuka lapangan kerja baru

e. Terjadi distribusi pendapatan. Masyarakat usaha produktif mampu melakukan aktivitas kerja, berarti mereka akan memperoleh pendapatan dari hasil usahanya. Penghasilan merupakan bagian dari pendapatan masyarakat.

Adapun secara mikro, pembiayaan diberikan dalam rangka untuk: 
a. Upaya memaksimalkan laba. Setiap usaha yang dibuka memiliki tujuan tertinggi, yaitu menghasilkan laba usaha. Setiap pengusaha menginginkan mampu mencapai laba maksimal. Untuk dapat menghasilkan laba maksimal maka mereka perlu dukungan dana yang cukup

b. Upaya meminimalkan risiko. Usaha yang dilakukan agar mampu menghasilkan laba maksimal, maka pengusaha harus mampu meminimalkan risiko yang mungkin timbul. Risiko kekurangan modal usaha dapat diperoleh melalui tindakan pembiayaan.

c. Pendayagunaan sumber ekonomi. Sumber daya ekonomi dapat dikembangkan dengan melakukan mixing antara sumber daya alam dengan sumber daya manusia serta sumber daya modal. Jika sumber daya alam dan sumber daya manusianya ada, dan sumber daya modal tidak ada, maka dipastikan diperlukan pembiayaan

d. Penyaluran kelebihan dana. Dalam kehidupan masyarakat ini ada pihak yang memiliki kelebihan sementara ada pihak yang kekurangan. Dalam kaitannya dengan masalah dana, maka mekanisme pembiayaan dapat menjadi pembiayaan dapat menjadi jembatan dalam penyeimbangan dana penyaluran kelebihan dana dari pihakyang berlebihan (surplus) kepada pihakyang kekurangan (minus) dana.

\section{3) Analisis Kelayakan Pembiayaan}

Menurut Kasmir dalam Astuti (2015) analisis kelayakan pembiayaan adalah suatu kegiatan penelitian secara mendalam terhadap suatu usaha untuk mengetahui layak atau tidaknya usaha tersebut dijalankan dan menentukan seberapa besar keuntungan atau kerugian yang akan timbul dari usaha tersebut. Pembiayaan yang diberikan kepada suatu usaha merupakan sumber pendapatan besar dalam operasional lembaga keuangan. Namun selain dapat mendatangkan keuntungan, pembiayaan juga mengandung tingkat resiko yang bervariasi dan dapat mengganggu likuiditas lembaga keuangan tersebut.

a. Prinsip-prinsip pemberian pembiayaan

Menurut Abdul dalam Astuti (2015) dalam melakukan penilaian
kriteriakriteria serta aspek penilaian tetap sama. Begitu pula dengan


ukuranukuran yang ditetapkan sudah menjadi standar penilaian setiap bank. Biasanya kriteria penilaian nasabah yang harus dilakukan oleh bank untuk mendapatkan nasabah yang benar-benar menguntungkan dilakukan dengan analisis $5 \mathrm{C}$ dan 7P. Prinsip analisis pembiayaan oleh calon nasabah $5 \mathrm{C}$ adalah:

a) Character atau watak (calon) nasabah

Dilihat dari kejujuran lewat investigasi yang dilakukan oleh maker, keadaan lingkungan keluarga (calon) nasabah, dan riwayat peminjaman yang telah lalu (apabila pernah melakukan pembiayaan). Selain itu hal yang terpenting yang harus diperhatikan adalah adanya unsur kemauan dari (calon) nasabah untuk melunasi pembiayaan yang diberikan oleh lembaga keuangan atau lembaga pembiayaan syariah yang bersangkutan.

b) Capital atau modal (calon) nasabah

Dalam modal ini yang dilihat adalah jumlah dana yang diperlukannya atau menjalankan kegiatan usahanya. Dengan kata lain, (calon) nasabah dalam mengajukan permohonan pembiayaan pun harus memiliki setidaknya uang muka untuk membuka rekening yang akan digunakan sebagai cara pelunasan pembiayaan nantinya.

c) Capacity atau kemampuan (calon) nasabah

Kemampuan (calon) nasabah untuk melunasi pembiayaan yang diberikan oleh $\mathrm{lks}$, dilihat dari usaha (calon) nasabah yang menjadi sumber pelunasan pembiayaan dimaksud. Disini pihak bank harus benarbenar memperhitungkan aspek-aspek yang ada antara lain: aspek hukum, pemasaran, keuangan, manajemen, dan analisis mengenai dampak lingkungan.

d) Condition atau kondisi ekonomi makro

Melihat faktor-faktor luar (ekonomi makro) yang mungkin terjadi dan dapat mempengaruhi kegiatan usaha calon nasabah yang menjadi sumber pelunasan dari pembiayaan bank/lks (lembaga keuangan syari'ah) yang diberikan kepadanya. 
e) Collateral atau agunan (calon) nasabah

Dalam hal pembiayaan murabahah yang dijadikan sebagi agunan adalah obyek dari pembiayaan murabahah itu sendiri. Namun apabila dari obyek pembiayaan murabahah tersebut dirasa tidak dapat mencukupi pembiayaan, maka bank dapat meminta barang lain untuk dijadikan agunan tambahan. Nilai dari agunan itu sendiri harus dapat menutupi jumlah dari pembiayaan yang dimohon oleh calon nasabah

Menurut Kasmir dalam Astuti (2015) penilaian pembiayaan dengan metode analisis 7P adalah:

a) Personality yaitu menilai nasabah dari segi kepribadiannya atau tingkah lakunya sehari-hari maupun masa lalunya. Personality juga mencakup sikap, emosi, tingkah laku, dan tindakan nasabah dalam menghadapi masalah.

b) Party yaitu mengklasifikasikan nasabah ke dalam klasifikasi tertentu atau golongan-golongan tertentu berdasarkan modal, loyalitas serta karakternya. Sehingga nasabah dapat digolongkan ke golongan tertentu dan akan mendapatkan fasilitas yang berbeda dari bank.

c) Purpose yaitu untuk mengetahui tujuan nasabah dalam mengambil pembiayaan, termasuk jenis pembiayaan yang diinginkan nasabah. Tujuan pengambilan pembiayaan dapat bermacam-macam.

d) Prospect yaitu untuk menilai usaha nasabah di masa yang akan datang menguntungkan atau tidak, atau dengan kata lain mempunyai prospect atau sebaliknya. Hal ini penting mengingat jika suatu fasilitas pembiayaan yang dibiayai tanpa mempunyai prospek, bukan hanya bank yang rugi, tetapi juga nasabah.

e) Payment merupakan ukuran bagaimana cara nasabah mengembalikan pembiayaan yang telah diambil atau dari sumber mana saja dana untuk pengembalian pembiayaan. Semakin banyak sumber penghasilan debitur, akan semakin baik. Dengan demikian, jika salah satu usahanya merugi akan dapat ditutupi oleh sektor lainnya. 
f) Profitability untuk menganalisis bagaimana kemampuan nasabah dalam mencari laba. Profitability diukur dari periode ke periode apakah akan tetap sama atau akan semakin meningkat, apalagi dengan tambahan pembiayaan yang akan diperoleh.

g) Protection tujuannya adalah bagaimana menjaga agar usaha dan jaminan mendapatkan perlindungan. Perlindungan dapat berupa jaminan barang atau orang atau jaminan asuransi.

\section{4) Prosedur Pembiayaan}

Menurut Arifin dalam Utomo (2018) prosedur pembiayaan adalah suatu gambaran yang bersifat atau metode untuk pelaksanaan suatu kegiatan pembiayaan. Pengertian tersebut menekankan bahwa prosedur adalah bagaimana cara melaksanakan suatu kegiatan mulai dari awak sampai selesai. Sehingga dengan adanya prosedur dapat membantu manusia dalam melakukan kegiatan tertentu.

Menurut kasmir dalam utomo (2018) tujuan dari prosedur pemberian kredit adalah untuk memastikan kelayakan suatu kredit, diterima atau ditolak.

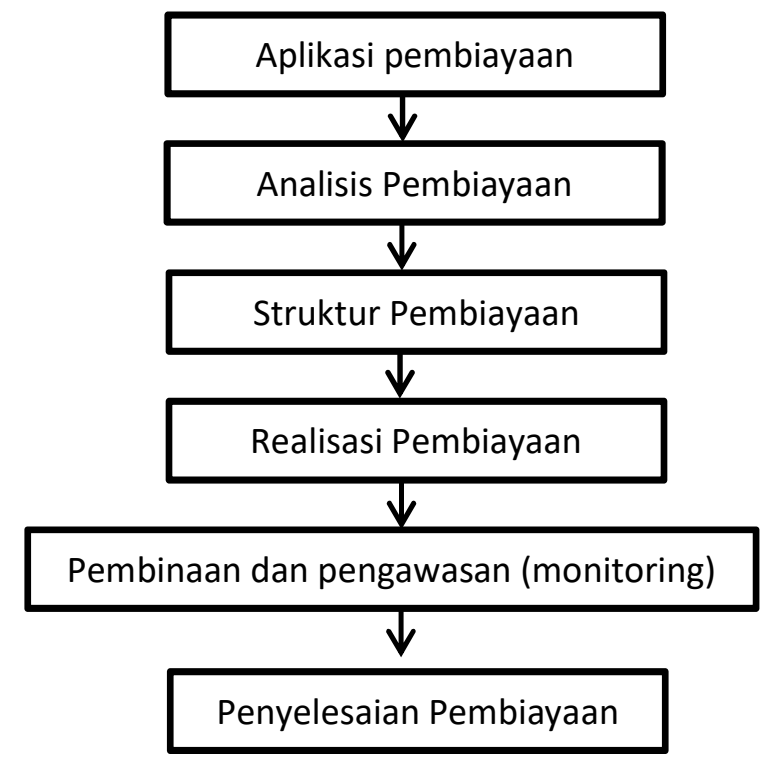

\section{Pembiayaan Mudharabah}

1) Pengertian pembiayaan mudharabah 
Menurut Meilindawati (2017) pembiayaan mudharabah merupakan akad pembiayaan anatara bank syariah sebagai shahibul maal dan nasabah sebagai mudharib untuk melaksanakan kegiatan usaha, di mana bank syariah memberikan modal sebanyak $100 \%$ dan nasabah menjalankan usahanya. Penyaluran dana dalambentuk pembiayaan berdasarkan pada kepercayaan yang diberikan kepada pemilik dana kepada pengguna dana. Pemilik dana percaya kepada penerima dana, bahwa dana dalam bentuk pembiayaan yang diberikan pasti akan terbayar. Penerima pembiayaan mendapat kepercayaan dari pemberi pembiayaan, sehingga penerima pembiayaan berkewajiban untuk mengembalikan pembiayaan yang telah diterimanya sesuai dengan jangka waktu yang telah diperjanjikan dalamakad pembiayaan.

\section{2) Syarat dan rukun pembiayaan mudharabah}

Menurut Jayadi dalam Permata (2014) syarat akad pembiayaan mudharabah ini adalah sebagai berikut :

a. Modal harus berupa uang atau barang yang dinilai, diketahui jumlahnya, harus tunai atau bukan piutang.

b. Keuntungan harus dibagi kedua pihak, besar keuntungan disepakati pada waktu awal kontrak, penyedia dana menanggung kerugian.

Rukun akad pembiayaan ini adalah sebagai berikut :

a. Pelaku akad

b. Objek akad

c. ljab dan qabul.

\section{3) Manfaat pembiayaan mudhrabah}

Menurut Khudori (2019) terdapat bebrapa manfaat dari pembiayaan mudharabah

a. Bank akan menikmati peningkatan bagi hasil pada saat keuntungan usaha nasabah meningkat.

b. Bank tidak berkewajiban membayar bagi hasil kepada nasabah pendanaan secara tetap, tetapi disesuaikan dengan pendapatan/hasil usaha bank sehingga bank tidak akan pernah mengalami negative spread. 
c. Pengembalian pokok pembiayaan disesuaikan dengan cash flow/arus kas usaha nasabah sehingga tidak memberatkan nasabah.

d. Bank akan lebih selektif dan hati-hati mencari usaha yang benarbenar aman, halal dan menguntungkan karena keuntungan yang konkrit dan benar-benar terjadi itulah yang akan dibagikan.

e. Prinsip bagi hasil dalam mudharabah ini berbeda dengan prinsip bunga tetap dimana bank akan menagih penerima pembiayaan satu jumlah bunga tetap berapapun keuntungan yang dihasilkan nasabah, sekalipun merugi dan terjadi krisis ekonomi.

\section{4) Jenis pembiayaan mudharabah}

Menurut PSAK 105 dalam Meilindawati (2017), kontrak mudharabah dapat dibagi atas dua jenis, yaitu mudharabah muqayyadah dan mudharabah muthlaqah.

a. Mudharabah Muqayyadah

Mudharabah muqayyadah adalah bentuk kerja sama antara pemilik dana dan pengelola, dengan kondisi pengelola dikenakan pembatasan oleh pemilik dana dalam hal tempat, cara, dan objek investasi. Dalam transaksi mudharabah muqayyadah, bank syariah bersifat sebagai agen yang menghubungkan shahibul maal dengan mudharib. Peran agen yang dilakukan bank syariah mirip dengan peran manajer investasi pada perusahaan sekuritas. Imbalan yang diterima oleh bank sebagai agen dinamakan fee dan bersifat tetap tanpa dipengaruhi oleh tingkat keuntungan yang dihasilkan oleh mudharib.

Mudharabah muqayyadah disebut juga dengan mudharabah terikat. Dalam praktik perbankan, mudharabah muqayyadah terdiri atas dua jenis, yaitu mudharabah muqayyadah executing dan mudharabah muqayyadah channeling.

b. Mudharabah Muthlaqah

Mudharabah muthlaqah adalah bentuk kerja sama antara pemilik dana dan pengelola tanpa adanya pembatasan oleh pemilik dana dalam hal tempat, cara, maupun objek investasi. Dalam hal ini, pemilik dana memberi 
kewenangan yang sangat luas kepada mudharib untuk menggunakan dana yang diinvestasikan. Kontrak mudharabah muthlaqah dalam perbankan syariah digunakan untuk tabungan maupun pembiayaan.

\section{Bagi Hasil}

\section{1) Pengertian bagi hasil}

Menurut Antonio dalam Yugiarto (2015) bagi hasil adalah suatu sistem pengolahan dana dalam perekonomian islam yakni pembagian hasil usaha antara pemilik modal (shahibul maal) dan pengelola (mudharib).

Muhammad dalam Yugiarto (2015) menjelaskan pelarangan riba dalam islam adalah suatu penolakan terhadap timbulnya risiko finansial tambahan yang ditetapkan dalam transaksi uang atau modal maupun jual beli yang dibebankan kepada satu pihak saja sedangkan pihak yang lain dijamin keuntungannya. Hal ini mengindikasikan perbankan syariah menganut sistem bagi hasil dalam proses kegiatannya dan mengharamkan bunga karena mengandung unsur riba.

Nisbah bagi hasil merupakan faktor utama dalam operasional bank syariah sehingga dalam penetapan nisbah bagi hasil bank perlu kebijakan yang tepat. Adapaun bahan pertimbangan dalam penetapan nisbah bagi hasil menurut Karim dalam Utomo (2018) sebagai berikut :

a. Referensi tingkat (marjin) keuntungan

b. Perkiraan tingkat keuntungan bisnis yang dibiayai perkiraan tingkat keuntungan bisnis/proyek yang dibiayai dihitung dengan mempertimbangkan sebagai berikut :

a) Perkiraan penjualan :

- Volume penjualan setiap transaksi atau volume penjualan setiap bulan

- Sales turn-over atau frekuensi penjualan setiap bulan

- Fluktuasi harga penjualan

- Rentang harga penjualan yang dapat dinegosiasikan

- Marjin keuntungan setiap transaksi

b) Lama cash to cash cycle : 
- Lama proses barang

- Lama persediaan

- Lama piutang

c) Perkiraan biaya-biaya langsung adalah biaya yang langsung berkaitan dengan kegiatan penjualan seperti biaya pengangkutan, biaya pengemasan dan biaya-biaya lain yang lazim.

d) Perkiraan biaya-biaya tidak langsung adalah biaya yang tidak langsung berkaitan dengan kegiatan penjualan, seperti biaya sewa kantor, biaya gaji karyawan dan biayabiaya lain yang yang lazim dikategorikan dalam overhead cost (ohc).

e) Delayed factor delayed factor adalah tambahan waktu yang ditambahkan pada cash to cash cycle untuk mengantisipasi timbulnya keterlambatan pembayaran dari nasabah ke bank.

\section{2) Prinsip Bagi Hasil}

Menurut Daulay dalam Yugiarto (2015) dalam sistem bagi hasil terdapat prinsip-prinsip untuk menjalankan aktivitasnya yaitu :

a. Prinsip keadilan dan kehati-hatian tercermin dari penerapan imbalan atas dasar bagi hasil dan pengambilan margin keuntungan yang disepakati bersama antara bank dengan nasabah kemudian bank sebagai pengelola akan mengembangkan dana yang terkumpul dari nasabah untuk usahausaha yang baik secara professional.

b. Prinsip kesederajatan, dimana menempatkan nasabah penyimpan dana, nasabah pengguna dana, maupun bank pada kedudukan yang sama dan sederajat. Hal ini tercermin dalam hak, kewajiban, risiko, dan keuntungan yang berimbang antara nasabah penyimpan dana, nasabah pengguna dana, maupun bank.

c. Prinsip ketentraman. Produk-produk bank syariah telah sesuai dengan prinsip dan kaidah muamalah islam, antara lain tidak adanya unsur riba serta penerapan zakat harta. Dengan demikian, nasabah akan merasakan ketentraman lahir maupun batin 
Menurut Nurhayati dan Wasilah dari Yugiarto (2015) dalam bagi hasil, penentuan nya dalam bentuk prosentase atau biasa disebut nisbah. Nisbah didefinisikan sebagai besaran yang digunakan untuk pembagian keuntungan. Nisbah mencerminkan imbalan yang berhak diterima oleh kedua pihak dan pemilik dana tidak boleh meminta pembagian keuntungan dengan menyatakan nilai nominal tertentu karena dapat menimbulkan riba. Nisbah harus diketahui jelas oleh kedua belah pihak. Jika dalam akad tidak dijelaskan masing-masing porsi maka pembagiannya menjadi $50 \%$ dan $50 \%$.

\section{Penelitian Terdahulu}

1) Utomo (2018) melakukan penelitian dengan judul " Analisis Pembiayaan Mudharabah Pada Bank Syariah Mandiri Kantor Cabang Pembantu Banyumanik". Hasil penelitian ini menunjukan bahwa prosedur pembiayaan mudharabah di BSM KCP Banyumanik dimulai dari permohonan pembiayaan nasabah dengan cara mengisi formuli atau aplikasi beserta menyertakan persyaratan awalan. Pengisian aplikasi tersebut didampingi dan dianalisa oleh AO. Berdasarkan analisa yang dilakukan oleh $\mathrm{AO}$ akan dilakukan komite yang sama tahap ini berfungsi untuk memutuskan apakah pembiayaan akan di ACC atau tidak. jika pembiayaan di setujui maka pengawai administrasi membuat SP3 (Surat Penegasan Pemberian Pembiayaan), dan melakukan akad pembiayaan oleh notaris. Berdasarkan SP3 dan akad tersebut menjdai dasar operating manager untuk melakukan pencairan pembiayaan kepada nasabah. Monitoring tersebut berupa pengawasan dan pembinaan terhadap nasabah dalam melakukan angsuran hingga pelunasan.

2) Vironika (2016) melakukan penelitian dengan judul "Analisis Pembiayaan Mudharabah Pada Bank Pembiayaan Rakyat Syariah (BPRS) Artha Amanan Ummat Ungaran". Hasil penelitian ini menunjukkan ketentuan dan prosedur pembiayaan mudharabah di BPRS Artha Amanah Ummat tidak jauh berbeda dengan jenis pembiayaan lainnya, yaitu pertama mengajukan permohonan dan melengkapi persyaratan, bersedia di survey dan adanya rapat komite bank untuk menentukan pembiayaan diterima atau ditolak. Dalam memeberikan pembiayaan Mudharabah AO pembiayaan menggunakan faktor 
analisis 5C (Character, Capacity, Collateral, Condition of economy) untuk membantu menentukan kelayakan pemberian pembiayaan.

\section{METODOLOGI PENELITIAN}

\section{Lokasi Dan Waktu Penelitian}

Penelitian dilakukan di bank syariah indonesia kc makassar pettarani yang beralamat jl. A pettarani no.70, tamamaung, kec. Pankkukang, kota makassar, sulawesi selatan. Waktu yang dibutuhkan penelitian ini sekitar 1-3 (satu sampai tiga) bulan

\section{Jenis Dan Sumber Data}

1) Jenis data

a. Data kualitatif yaitu data yang diperoleh dari bank dalam bentuk informasi baik secara lisan maupun tulisan untuk memperoleh gambara umum tentang pembiayaan mudharabah.

b. Data kuantitatif yaitu data yang diperoleh dari bank dalam bentuk angkaangka yang berhubungan dengan pembiayaan mudharabah dan bagi hasil.

2) Sumber data

a. Data primer yaitu data yang di peroleh secara langsung dari bank syariah indonesia kc makassar pettarani berdasarkan hasil observasi dan wawancara dengan pimpinan ataupun karyawan.

b. Data sekunder yaitu data yang diperoleh informasi dan daftar pustaka, serta bahan-bahan yang berhubungan dengan masalah yang diteliti.

\section{Teknik Pengumpulan Data}

Pengambilan data dan keterangan yang diperlukan pada penelitian ini, maka penulis menggunakan pengumpulan data sebagai berikut:

1) Penelitian pustaka (library reserch) yaitu suatu teknik pengumpulan data teoritis dengan cara menelaah buku literature dan bahan pustaka lainnya yang berkaitan dengan masalah yang dibahas. 
2) Penelitian lapangan (field reserch) yaitu pengumpulan data dengan pengamatan secara langsung terhadap objek yang di teliti dengan cara-cara sebagai berikut:

a. Observasi yaitu pengumpulan data dengan pengamatan secara langsung terhadap objek yang diteliti. Sehingga diperoleh informasi yang jelas mengenai objek penelitian pada bank syariah indonesia kc makassar pettarani.

b. Wawancara yaitu dilakukan tanya jawab dengan pimpinan atau karyawan perusahaan yang di teliti dalam mendapatkan data dan informasi yang diperlukan.

\section{Populasi Dan Sampel}

Menurut Siagian dalam Daga (2021) populasi merupakan totalitas dari semua objek atau individu yang memiliki karakteristik tertentu jelas dan lengkap yang akan diteliti.

Penelitian ini dilakukan untuk meneliti pembiayaan mudharabah, maka yang menjadi populasi dalam penelitian ini adalah jumlah pembiaayan mudharabah pada bank syariah indonesia kc makassar pettarani.

Menurut ibid dalam aguspian (2012) sampel adalah memperoleh keterangan mengenai objek penelitian dengan cara mengamati sebagian dari populasi suatu reduksi terhadap objek penelitian. Berdasarkan kriteria tersebut maka sampel yang akan diambil selama periode tahun 2018-2020 sebanyak 3 sampel.

\section{Analisis Data}

Metode analisi data yang digunakan adalah deskriptif kualitatif, yaitu dengan mengumpulkan informasi dari perusahaan dan menganalisisnya dengan cara mendeskripsikan.

\section{Definisi Operasional}

1. Bank syariah adalah lembaga keuangan intermediasi keuangan, yang dalam menjalankan kegiatan operasionalnya berdasarkan prinsip syariah.

2. Pembiaayaan adalah jenis transaksi dimana penyedia dana atau shahibul maal dan pengelolah dana atau mudharib melakukan akad berdasarkan dengan prinsip-prinsip syariah. 
3. Pembiayaan mudharabah adalah pembiayaan yang dimana pihak penyedia dana (shahibul maal) memberikan dana 100\% dan memberikan tanggung jawab kepada pihak pengelolah dana (mudharib) dimana sistem bagi hasilnya berdasarkan perjanjian di awal ketika melakukan akad.

\section{KESIMPULAN}

Berdasarkan tinjauan pustaka diatas dapat disimpulkan bahwa pembiayaan mudharabah memiliki prosedur yang sama di semua bank syariah ketika mengajukan pembiayaan dibank syariah, dimana diawali pengajuan surat permohonan kemudian dilanjutkan dengan prosedur lainnya. Sedangkan untuk pembagian bagi hasil dapat dilakukan pada saat dilaksanakannya akad. Adapun besar dari bagi hasil yang diberikan tergantung kesepakatan antara bank dan nasabah yang bersangkutan. 


\section{DAFTAR PUSTAKA}

Aguspian, A. (2012). Analisis Pembiayaan Mudharabha Terhadap Tingkat Profitabilitas (Profit Margin) pada PT. Bank Sulselbar Cabang Syariah Makassar (Doctoral dissertation, Universitas Islam Negeri Alauddin Makassar).

Ardiansyah, d. (2012). Implementasi pembiayaan dengan akad mudharabah (studi pada 3 bank syariah di kota malang). Jurnal ilmiah mahasiswa feb, 1(2).

Astuti, a. F. (2015). Analisis kelayakan pembiayaan murabahah di bank pembiayaan rakyat syariah (bprs) sukowati sragen cabang boyolali (doctoral dissertation, iain salatiga).

Daga, R. (2021). ANALISIS STRATEGI PEMASARAN DALAM PENINGKATAN PEMBIAYAAN KONSUMTIF PADA PT BANK RAKYAT INDONESIA SYARIAH, TbK KANTOR CABANG PEMBANTU GOWA SUNGGUMINASA.

Daga, R. (2021). Faktor-Faktor Yang Mempengaruhi Loyalitas Karyawan Pada Pt. Bank Syariah Mandiri Kantor Cabang Makassar.

Khudori, s. (2019). Analisis kepatuhan syariah implementasi prinsip bagi hasil pada simpanan mudharabah di kspps binamas purworejo. At-tauzi: islamic economic journal, 19(1), 18-34.

Marimin, A., \& Romdhoni, A. H. (2015). Perkembangan bank syariah di Indonesia. Jurnal IImiah Ekonomi Islam, 1(02).

Meilindawati, R. M. (2017). PEMBAHASAN PEMBIAYAN MUDHARABAH.

Permata, R. I. D. (2014). Analisis Pengaruh Pembiayaan Mudharabah Dan Musyarakah Terhadap Tingkat Profitabilitas (Return On Equity)(Studi pada Bank Umum Syariah Yang Terdaftar di Bank Indonesia Periode 2009-2012). Jurnal Administrasi Bisnis, 12(1). 
Rimadhani, m., \& erza, o. (2017). Analisis variabel-variabel yang mempengaruhi pembiayaan murabahah pada bank syariah mandiri periode 2008.012011.12. Media ekonomi, 19(1), 27-52.

Utomo, b. (2018). Analisis pembiayaan mudharabah pada bank syariah mandiri kantor cabang pembantu banyumanik (doctoral dissertation, iain salatiga).

Veronika, D. (2018). ANALISIS PEMBIAYAAN MUDHARABAH PADA BANK PEMBIAYAAN RAKYAT SYARIAH (BPRS) ARTHA AMANAH UMMAT UNGARAN (Doctoral dissertation, IAIN SALATIGA).

Yogiarto, a. H. P. (2015). Pengaruh bagi hasil, promosi, dan kualitas pelayanan terhadap keputusan penggunaan jasa perbankan syariah tabungan mudharabah. Skripsi. Universitas negeri yogyakarta. 